\title{
HUBUNGAN ANTARA ASUPAN ASAM LEMAK TRANS DENGAN PERSEN LEMAK TUBUH DAN STATUS GIZI PADA ORANG DEWASA DI KABUPATEN DAN KOTA BOGOR
}

\author{
(Correlation between Intake of Trans Fatty Acid and Body Fat Percentage and Nutritional Status in \\ the District and the City of Bogor)
}

Zaenudin $^{1 *}$, Mira Dewi ${ }^{1}$, dan Yekti Hartati Effendi ${ }^{1}$ 'Departemen Gizi Masyarakat, Fakultas Ekologi Manusia (FEMA), Institut Pertanian Bogor,
Jl. Raya Darmaga, Bogor 16880

\begin{abstract}
The objective of this study was to determine relationship between trans fatty acid intake with percentage of body fat and nutritional status among adults in Bogor rural and urban area. The research was conducted using a cross sectional study. The number of subjects for each region was 48 adults aged 20-65 years which selected purposively. The results showed that most of subjects in urban and rural areas were in categorized as high deficient of energy $(<70 \%$ RDA), i.e. $29.17 \%$ and $33.33 \%$, respectively. The percentage of fat adequacy was $43.75 \%$ in rural area, which was categorized as sufficient, and $45.83 \%$ in urban area, which was categorized as high. Meanwhile, most of the subjects (97.92\%) in both areas had adequacy level of trans fatty acid intake

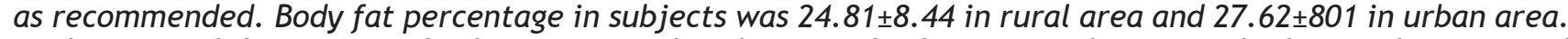
In the meanwhile, $58.30 \%$ of subjects in rural and $64.4 \%$ of subjects in urban areas had normal nutritional status. There was no significant difference $(p>0.05)$ between trans fatty acid intake, adequacy level intakes of energy, total fat, trans fatty acid, and body fat percentage. However there was a significant difference between nutritional status of subjects in rural and urban areas $(p<0.05)$. There was no relationship between adequacy level intakes of energy, total fat, and trans fatty acid, with body fat percentage and nutritional status ( $p>0.05$ ), but there was significant correlation between body fat percentages and nutritional status of subjects $(p<0.05)$.
\end{abstract}

Keywords: adult, body fat percentage, nutritional status, trans fatty acid

\begin{abstract}
ABSTRAK
Tujuan dari penelitian ini adalah untuk mengetahui hubungan antara asupan asam lemak trans dengan persen lemak tubuh dan status gizi pada orang dewasa di Kabupaten dan Kota Bogor. Penelitian menggunakan desain cross sectional. Jumlah subjek untuk masing-masing wilayah terdiri dari 48 orang dewasa yang berusia 20 65 tahun yang dipilih secara purposive. Persentase tingkat kecukupan energi subjek terbesar baik wilayah kabupaten (33.33\%) maupun kota (29.17\%) adalah defisit berat. Persentase tingkat kecukupan lemak total subjek terbesar untuk wilayah kabupaten adalah cukup (43.75\%), sedangkan persentase tingkat kecukupan lemak total subjek terbesar untuk wilayah kota adalah lebih (45.83\%). Sebagian besar subjek baik di wilayah kabupaten maupun kota memiliki tingkat kecukupan lemak trans yang sesuai anjuran (97.92\%). Rata-rata persen lemak tubuh subjek untuk wilayah kabupaten adalah $24.81 \pm 8.44$, sedangkan untuk wilayah kota adalah $27.62 \pm 8.01$. Sebaran persen lemak tubuh subjek dengan persentase terbesar baik wilayah kabupaten $(60.40 \%)$ maupun kota $(48.00 \%)$ adalah persen lemak tubuh tinggi. Sebaran subjek di wilayah kabupaten $(58.30 \%)$ maupun kota $(64.40 \%)$ memiliki persentase terbesar pada status gizi normal. Tidak terdapat perbedaan yang nyata antara tingkat kecukupan energi, lemak total, lemak trans, dan persen lemak tubuh subjek di wilayah kabupaten dengan wilayah kota $(p>0.05)$. Terdapat perbedaan yang nyata antara status gizi subjek di wilayah kabupaten dengan wilayah kota $(p<0.05)$. Tidak terdapat hubungan yang signifikan antara asupan lemak trans, tingkat kecukupan energi, lemak total, dan lemak trans dengan persen lemak tubuh dan status gizi subjek ( $>0.05$ ), akan tetapi terdapat hubungan yang signifikan antara persen lemak tubuh dengan status gizi subjek $(p<0.05)$.
\end{abstract}

Kata kunci: dewasa, lemak trans, persen lemak tubuh, status gizi

"Korespondensi: Departemen Gizi Masyarakat, Fakultas Ekologi Manusia (FEMA), Institut Pertanian Bogor, Jl. Raya Darmaga, Bogor 16880; Email: zaenudinsgz@yahoo.com 


\section{PENDAHULUAN}

Keadaan gizi lebih dengan konsekuensi timbulnya penyakit degeneratif telah melanda Indonesia, oleh karena itu pencegahan penyakit kronis yang tergolong sebagai penyakit degeneratif yang seringkali menyertai keadaan gizi lebih perlu ditingkatkan. Studi observasional juga menunjukkan bahwa obesitas meningkatkan risiko terjadinya penyakit kardiovaskular baik pada wanita maupun pria dewasa (Mawi 2004).

Menurut Muchtadi (2001), kegemukan (obesitas) banyak terjadi pada individu-individu di negara maju. Timbulnya kegemukan ini dapat dihubungkan dengan meningkatnya densitas energi dalam makanan/minuman yang menyertai meningkatnya kemakmuran. Hasil penelitian Riskesdas (2010) menunjukkan bahwa konsumsi pangan tinggi lemak dan prevalensi obesitas masyarakat perkotaan lebih tinggi dibandingkan masyarakat pedesaaan.

Saat ini orang dewasa sering mengonsumsi makanan-makanan fast food yang mengandung energi, lemak, dan garam cukup tinggi, tetapi sedikit kandungan vitamin, mineral, dan serat. Kebanyakan dari makanan-makanan fast food tinggi kandungan lemak jenuh yang tidak baik bagi kesehatan (Paeratakul et al. 2003). Diet tinggi energi dan lemak pada orang barat telah mengakibatkan tingginya asam lemak jenuh pada sistem kardiovaskular dan dengan rendahnya aktivitas fisik menjadikan lemak jenuh tersebut akan terakumulasi dalam lemak tubuh (Angelieri 2012).

Selain lemak jenuh, salah satu jenis lemak tak jenuh yang juga diketahui berpengaruh buruk terhadap kesehatan adalah asam lemak trans atau sering disebut juga dengan Trans Fatty Acid (TFA). TFA merupakan faktor risiko yang penting pada PJK. Sama seperti pengaruh asam lemak jenuh, konsumsi TFA juga menimbulkan pengaruh negatif karena menaikkan kadar LDL, bahkan TFA juga akan menurunkan HDL dalam darah, sedangkan asam lemak jenuh tidak akan memengaruhi HDL dalam darah (Silalahi \& Tampubolon 2002, Mozaffarian et al. 2006).

TFA yang dikonsumsi manusia umumnya berasal dari makanan siap saji (fast food) dan pangan yang digoreng, menggunakan margarin. Selain margarin dan fast food, hasil penelitian U.S. Food and Drug Administration pada tahun 2003 menyebutkan bahwa produk makanan seperti roti, kue, kerupuk, kentang beku, snack asin, minyak sayur yang mengandung shortening, mayones, dan sereal sarapan kering juga merupakan jenis pangan yang mengandung asam lemak trans (Satchithanandam et al. 2004).

Kebanyakan penelitian mengenai pengaruh TFA hanya terkait bidang kesehatan dan masih sedikit penelitian mengenai pengaruh TFA terhadap simpanan lemak tubuh dan status gizi , akan tetapi hasil penelitian Anderson et al. (2010) menunjukkan bahwa terdapat pengaruh dari asupan lemak trans terhadap komposisi lemak tubuh ibu dan bayi pasca kelahiran. Selain itu, asupan TFA juga dapat mengganggu metabolisme asam lemak esensial yang baik bagi perkembangan bayi (Innis 2006). Pengaruh asupan lemak trans terhadap peningkatan simpanan lemak dalam tubuh juga membutuhkan waktu yang cukup lama (Banerjee et al. 2003). Oleh karena itu, diperlukan penelitian lebih lanjut untuk mengetahui pengaruh dari konsumsi asam lemak trans terhadap simpanan lemak tubuh (persen lemak tubuh) dan status gizi.

Tujuan umum dari penelitian ini adalah untuk mengetahui hubungan antara konsumsi asam lemak trans dengan persen lemak tubuh dan status gizi pada orang dewasa di Kabupaten dan Kota Bogor.

\section{METODE}

\section{Desain, Tempat, dan Waktu}

Penelitian ini merupakan bagian dari penelitian payung yang berjudul Asupan Fitosterol dari Pangan pada Masyarakat di Wilayah Bogor. Penelitian ini menggunakan desain cross sectional yang dilakukan pada bulan Mei sampai Juli 2012 di wilayah Kabupaten dan Kota Bogor. Wilayah kabupaten terdiri dari Kecamatan Dramaga dan Kecamatan Ciampea, sedangkan wilayah kota terdiri dari Kecamatan Bogor Selatan dan Kecamatan Bogor Timur. Wilayah kabupaten meliputi tiga kelurahan, yaitu Kecamatan Dramaga terdiri dari Kelurahan Dramaga dan Cikarawang, sedangkan Kecamatan Ciampea di Kelurahan Cihideung Ilir. Wilayah kota juga meliputi tiga kelurahan, yaitu Kecamatan Bogor Selatan terdiri dari Kelurahan Empang dan Lawang Gintung, sedangkan Kecamatan Bogor Timur di Kelurahan Sukasari.

\section{Jumlah dan Cara Penarikan Subjek}

Pemilihan kelurahan sebagai lokasi penelitian ditentukan secara purposive dengan pertimbangan bahwa masing-masing kelurahan memiliki kriteria yang sama atau homogen dan keterjangkauan peneliti ke wilayah-wilayah tersebut. Kriteria inklusi subjek dalam penelitian ini adalah laki-laki dan perempuan dewasa berusia 20-65 tahun dan bersedia untuk diwawancarai, sedangkan kriteria eksklusi adalah subjek memiliki riwayat penyakit. Jumlah populasi yang memenuhi kriteria inklusi dalam penelitian ini adalah 49794 orang. Berdasarkan perhitungan menggunakan rumus Lemeshowb et al. (1997), ukuran minimal subjek adalah 48 subjek.

Berdasarkan hasil penarikan subjek secara random sample proporsional, maka jumlah subjek yang terpilih di Kelurahan Dramaga adalah sebanyak 15 subjek, di Kelurahan Cikarawang sebanyak 14 subjek, dan di Kelurahan Cihideung Ilir sebanyak 19 subjek pada wilayah Kabupaten Bogor, sedangkan 
jumlah subjek yang terpilih di Kelurahan Empang sebanyak 22 subjek, di Kelurahan Lawang Gintung sebanyak 15 subjek, dan di Kelurahan Sukasari sebanyak 11 subjek untuk wilayah Kota Bogor.

\section{Jenis dan Cara Pengumpulan Data}

Data yang digunakan dalam penelitian ini terdiri dari data jenis kelamin, usia, pendidikan, pekerjaan, pendapatan, dan besar keluarga, konsumsi makanan dan minuman (pagi, siang, malam, dan selingan) selama 2 hari, persen lemak tubuh berdasarkan berat badan, dan status gizi berdasarkan IMT (berat badan dan tinggi badan). Pengumpulan data karakteristik sosial ekonomi dan konsumsi makanan dan minuman dilakukan dengan wawancara menggunakan kuesioner sedangkan untuk data persen lemak tubuh dikumpulkan dengan pengukuran menggunakan alat Body Fat Monitoring (Omron), dan data antropometri dikumpulkan dengan cara penimbangan berat badan menggunakan timbangan injak dan pengukuran tinggi badan menggunakan microtoise. Data sekunder meliputi profil wilayah (gambaran umum wilayah kabupaten dan kota Bogor, serta jumlah penduduk laki-laki dan perempuan yang berusia 20-65 tahun) dan data Angka Kecukupan Gizi (energi, protein, lemak total, asam lemak trans) berdasarkan usia subjek.

\section{Pengolahan dan Analisis Data}

Pengolahan data karakteristik sosial ekonomi subjek dianalisis secara deskriptif. Data konsumsi makanan subjek dalam satuan Ukuran Rumah Tangga (URT) diubah ke dalam satuan gram dan dikonversikan ke dalam bentuk asupan energi, protein, dan lemak total menggunakan data dalam Daftar Komposisi Bahan Makanan (DKBM), sedangkan asupan asam lemak trans menggunakan data dari USDA (2011). Perhitungan Angka Kecukupan Lemak (AKL) total menggunakan perhitungan 20-30\% dari kecukupan energi masing-masing subjek (WNPG 2004), sedangkan angka kecukupan asam lemak trans menggunakan perhitungan $<1 \%$ asupan energi masing-masing subjek (WHO 2008). Tingkat Kecukupan Lemak (TKL) total dihitung dengan membandingkan asupan lemak total masing-masing subjek dengan AKL total dan diklasifikasikan menjadi kurang (<20\% dari asupan E), cukup (20-30\% dari asupan E), dan lebih (>30\% dari asupan E), sedangkan TKL trans dihitung dengan membandingkan asupan asam lemak trans masing-masing subjek dengan AKL trans dan diklasifikasikan menjadi sesuai anjuran (<1\% dari asupan E) dan tidak sesuai anjuran ( $\geq$ dari asupan $E$ ).

Data persen lemak tubuh diolah dengan mengelompokkan berdasarkan jenis kelamin, kemudian diklasifikasikan berdasarkan standar alat Omron sebagai "kurang" (<10\% untuk laki-laki dan <20\% untuk perempuan), "normal” (10\%-20\% untuk laki-laki dan 20-30\% untuk perempuan), dan "lebih" (>20\% untuk laki-laki dan >30\% untuk perempuan). Status gizi dihitung berdasarkan rumus Indeks Massa Tubuh (IMT), dan diklasifikasikan berdasarkan IMT menurut standar WHO (2004).

Analisis statistik yang digunakan, antara lain uji beda Independent Sample T-Test yang digunakan untuk melihat perbedaan asupan asam lemak trans, tingkat kecukupan, lemak total, lemak trans, persen lemak tubuh, dan status gizi antara subjek di Kabupaten dengan di Kota Bogor. Uji korelasi Pearson dan Spearman digunakan untuk melihat hubungan antara tingkat kecukupan energi, lemak total, dan lemak trans dengan persen lemak tubuh dan status gizi subjek.

\section{HASIL DAN PEMBAHASAN}

Bogor terbagi menjadi dua wilayah, yaitu kota dan kabupaten. Secara sosial ekonomi, wilayah kabupaten berbeda dengan wilayah kota, baik dari jumlah penduduk, pendidikan, pekerjaan, maupun pendapatan. Wilayah kabupaten lebih didominasi oleh sektor pertanian, perikanan, dan kehutanan yang sangat berperan penting dalam perekonomian masyarakat di Kabupaten Bogor. Wilayah Kota Bogor lebih didominasi oleh bidang pariwisata. Kabupaten Bogor terdiri dari 40 kecamatan dengan jumlah total kelurahan paling banyak di Provinsi Jawa Barat, yaitu berjumlah 428 kelurahan, sedangkan Kota Bogor hanya terdiri dari 6 kecamatan dan 68 kelurahan. Jumlah penduduk di Kabupaten Bogor mencapai 4779578 orang, sedangkan jumlah penduduk di Kota Bogor mencapai 950334 orang (BPS 2010).

\section{Karakteristik Sosial Ekonomi Subjek}

Tabel 1 menunjukkan sebaran karakteristik sosial ekonomi subjek. Sebagian besar subjek baik di wilayah kabupaten (58.30\%) maupun kota (64.60\%) berjenis kelamin perempuan. Sebagian besar usia subjek baik di wilayah kabupaten (58.30\%) maupun kota (62.50\%) termasuk ke dalam kelompok dewasa dini dengan rata-rata usia 39.80 2 2.76 untuk wilayah kabupaten dan $39 \pm 11.56$ untuk wilayah kota. Sebagian besar pendidikan terakhir subjek di wilayah kabupaten adalah SD/sederajat (39.60\%), sedangkan pendidikan terakhir subjek di wilayah kota adalah SMA (35.4\%). Sebagian besar pekerjaan subjek baik di wilayah kabupaten (48\%) maupun kota (41.70\%) adalah ibu rumah tangga. Sebagian besar pendapatan per kapita keluarga subjek baik di wilayah kabupaten (58.30\%) maupun kota (72.90\%) termasuk dalam kelompok keluarga tidak miskin dengan ratarata pendapatan per kapita keluarga subjek Rp 301 808.61 296721.65 untuk wilayah kabupaten dan Rp $518098.96 \pm 486392.95$ untuk wilayah kota. Besar keluarga subjek baik di wilayah kabupaten maupun kota dengan persentase terbesar termasuk dalam kelompok keluarga kecil, yaitu sebesar $60.40 \%$ un- 
Zaenudin dkk.

Tabel 1. Sebaran Karakteristik Sosial Ekonomi Subjek

\begin{tabular}{|c|c|c|c|c|}
\hline \multirow{2}{*}{ Jenis Data } & \multicolumn{2}{|c|}{ Kabupaten Bogor } & \multicolumn{2}{|c|}{ Kota Bogor } \\
\hline & $\mathrm{n}$ & $\%$ & $\mathrm{n}$ & $\%$ \\
\hline \multicolumn{5}{|l|}{ Jenis Kelamin: } \\
\hline -Laki-Laki & 20 & 41.70 & 17 & 35.40 \\
\hline -Perempuan & 28 & 58.30 & 31 & 64.60 \\
\hline \multicolumn{5}{|l|}{ Usia: } \\
\hline -Dewasa Awal & 28 & 58.30 & 30 & 62.50 \\
\hline -Dewasa Madya & 16 & 33.40 & 14 & 29.20 \\
\hline -Dewasa Akhir & 4 & 8.30 & 4 & 8.30 \\
\hline \multicolumn{5}{|l|}{ Pendidikan: } \\
\hline -Tidak Lulus SD & 3 & 6.20 & 2 & 4.20 \\
\hline -SD/sederajat & 19 & 39.60 & 13 & 27.10 \\
\hline -SMP/sederajat & 13 & 27.10 & 9 & 18.70 \\
\hline -SMA/sederajat & 11 & 22.90 & 17 & 35.40 \\
\hline -Diploma/sederajat & 0 & 0.00 & 3 & 6.20 \\
\hline -Sarjana/sederajat & 2 & 4.20 & 4 & 8.40 \\
\hline \multicolumn{5}{|l|}{ Pekerjaan: } \\
\hline -Petani & 1 & 2.10 & 0 & 0 \\
\hline -Pedagang & 5 & 10.40 & 4 & 8.30 \\
\hline -Wiraswasta & 4 & 8.30 & 5 & 10.40 \\
\hline -Pegawai Swasta & 3 & 6.30 & 0 & 0 \\
\hline -PNS & 1 & 2.10 & 4 & 8.30 \\
\hline -Polisi/TNI & 0 & 0.00 & 6 & 12.60 \\
\hline - Lainnya & 34 & 70.80 & 29 & 60.40 \\
\hline \multicolumn{5}{|l|}{ Pendapatan: } \\
\hline -Miskin ( $\leq$ Rp 220 098) & 20 & 41.70 & 12 & 27.10 \\
\hline -Tidak miskin (>Rp 220 098) & 28 & 58.30 & 36 & 72.90 \\
\hline \multicolumn{5}{|l|}{-Besar Keluarga } \\
\hline -Keluarga kecil ( $\leq 4$ orang) & 29 & 60.40 & 31 & 64.60 \\
\hline -Keluarga sedang ( $5-7$ orang) & 16 & 33.30 & 16 & 33.30 \\
\hline -Keluarga besar ( $\geq 8$ orang) & 3 & 6.30 & 1 & 2.10 \\
\hline
\end{tabular}

tuk wilayah kabupaten dan $64.60 \%$ untuk wilayah kota.

\section{Asupan Zat Gizi}

Rata-rata asupan energi subjek untuk wilayah kabupaten sebesar $1634 \pm 566$ kkal dengan asupan yang berkisar antara 541-3 $540 \mathrm{kkal}$, relatif sama dengan rata-rata asupan energi subjek untuk wilayah kota sebesar $1623 \pm 451$ kkal dan berkisar antara 871-2 979 kkal. Rata-rata asupan protein subjek untuk wilayah kabupaten sebesar $48 \pm 20.88$ g dengan asupan yang berkisar antara 14.25-116.79 $\mathrm{g}$, lebih rendah dibandingkan rata-rata asupan protein subjek untuk wilayah kota sebesar $50 \pm 20.58 \mathrm{~g}$ dengan asupan yang berkisar antara $20.58-119.39 \mathrm{~g}$. Rata-rata asupan lemak total subjek untuk wilayah kabupaten sebesar $50 \pm 21.02 \mathrm{~g}$ dengan asupan yang berkisar antara 11.97-95.03 g, sedangkan rata-rata asupan lemak total subjek untuk wilayah kota sebesar $53 \pm 21.75 \mathrm{~g}$ dengan asupan yang berkisar antara 19.44-103.40 g. Rata-rata asupan lemak trans subjek untuk wilayah kabupaten sebesar $0.40 \pm 0.38 \mathrm{~g}$ dengan asupan yang berkisar antara $0-2.22 \mathrm{~g}$, sedangkan rata-rata asupan lemak trans subjek untuk wilayah kota sebesar $0.41 \pm 0.51 \mathrm{~g}$ dengan asupan yang berkisar antara $0-3.26 \mathrm{~g}$.

\section{Tingkat Kecukupan Zat Gizi}

Sebanyak $33.33 \%$ subjek di wilayah kabupaten dan $29.17 \%$ di wilayah kota mengalami defisit berat dalam hal tingkat kecukupan energi. Sebanyak $31.25 \%$ subjek di wilayah kabupaten memiliki tingkat kecukupan protein defisit berat dan normal, sedangkan di wilayah kota sebanyak $29.17 \%$ subjek memiliki tingkat kecukupan protein normal. Sebanyak $43.75 \%$ subjek di wilayah kabupaten memiliki 
Tabel 2. Sebaran Rata-rata Persen Lemak Tubuh dan IMT Subjek

\begin{tabular}{cccccc}
\hline \multirow{2}{*}{ No } & \multirow{2}{*}{ Keterangan } & \multicolumn{2}{c}{ Wilayah } & \multicolumn{2}{c}{ Jenis Kelamin } \\
\cline { 3 - 6 } & & Kabupaten & Kota & Laki-Laki & Perempuan \\
\hline 1 & \% Lemak Tubuh & $24.81 \pm 8.44$ & $27.62 \pm 8.01$ & $26.02 \pm 8.30$ & $26.24 \pm 8.34$ \\
2 & IMT & $22.57 \pm 3.45$ & $24.26 \pm 4.26$ & $21.52 \pm 2.72$ & $24.61 \pm 4.15$ \\
\hline
\end{tabular}

tingkat kecukupan lemak total cukup, sedangkan di wilayah kota sebanyak $45.83 \%$ subjek di wilayah kota memiliki tingkat kecukupan lemak total lebih. Sebanyak $97.92 \%$ subjek baik di wilayah kabupaten maupun kota memiliki tingkat kecukupan lemak trans yang sesuai anjuran.

\section{Persen Lemak Tubuh}

Sebagian besar subjek baik wilayah kabupaten (48\%) maupun kota $(60.40 \%)$ memiliki persen lemak tubuh tinggi dengan rata-rata persen lemak tubuh subjek untuk wilayah kabupaten adalah $24.81 \pm 8.44$, sedangkan untuk wilayah kota adalah $27.62 \pm 8.01$. Jika dibedakan berdasarkan jenis kelamin, sebagian besar subjek baik laki-laki (51.40\%) maupun perempuan $(55.90 \%)$ juga memiliki persen lemak tubuh tinggi.

\section{Status Gizi}

Sebagian besar subjek baik di wilayah kabupaten $(58.30 \%)$ maupun kota $(64.40 \%)$ memiliki status gizi normal dengan rata-rata IMT untuk wilayah kabupaten adalah $22.57 \pm 3.45$, sedangkan untuk wilayah kota adalah $24.26 \pm 4$.26. Jika dibedakan berdasarkan jenis kelamin, sebagian besar status gizi subjek baik laki-laki (73\%) maupun perempuan (54.20\%) juga memiliki status gizi normal. Subjek dengan status gizi obes I dan obes II di wilayah kota masing-masing adalah $8.3 \%$ dan $2.1 \%$, sedangkan subjek di wilayah kabupaten tidak ada yang memiliki status gizi obes. Dalam penelitian Sawaswati dan Dieny (2012) menyebutkan bahwa prevalensi obes di kota lebih tinggi daripada di desa. Hasil penelitian Riskesdas (2010) juga menyatakan bahwa prevalensi obes lebih tinggi di daerah perkotaan dibanding pedesaan, selain itu prevalensi obes pada lakilaki lebih rendah $(16.30 \%)$ dibanding perempuan (26.90\%), sedangkan prevalensi penduduk dewasa laki-laki yang kurus lebih tinggi (12.90\%) dibandingkan perempuan $(12.30 \%)$. Sebaran rata-rata persen lemak tubuh dan IMT subjek disajikan pada Tabel 2.

\section{Hubungan antara Asupan Asam Lemak Trans de- ngan Persen Lemak Tubuh dan Status Gizi}

Berdasarkan hasil uji beda Independent Sample T-Test dapat diketahui bahwa tidak terdapat perbedaan yang nyata antara asupan asam lemak trans, tingkat kecukupan energi, lemak total, asam lemak trans, dan persen lemak tubuh subjek di wilayah kabupaten dengan wilayah kota ( $p>0.05)$, akan tetapi terdapat perbedaan yang nyata antara status gizi subjek di wilayah kabupaten dengan wilayah kota $(p<0.05)$.

Berdasarkan hasil uji korelasi Pearson dan Spearman dapat diketahui bahwa tidak terdapat hubungan yang signifikan antara tingkat kecukupan energi, lemak total, dan asam lemak trans dengan persen lemak tubuh dan status gizi subjek ( $p>0.05$ ), akan tetapi terdapat hubungan yang signifikan antara persen lemak tubuh dengan status gizi subjek $(p<0.05 ; r=0.66)$.

\section{KESIMPULAN}

Hasil penelitian menunjukkan bahwa terdapat perbedaan yang nyata antara status gizi subjek di wilayah kabupaten dengan wilayah kota. Selain itu, terdapat hubungan yang signifikan antara persen lemak tubuh dengan status gizi subjek. Penelitian lanjutan mengenai topik serupa diharapkan menggunakan metode yang lebih baik dalam pengukuran konsumsi makanan dan minuman subjek, seperti Food Frequency Questionnairre (FFQ) sehingga lebih menggambarkan pola konsumsi subjek.

\section{DAFTAR PUSTAKA}

Anderson AK, McDougald DM \& Asiedu M. 2010. Dietary trans fatty acid intake and maternal and infant adiposity. European Journal of Clinical Nutrition, 64(11), 1-8.

Angelieri CT. 2012. Trans fatty acid intake is associated with insulin sensitivity but independently of inflammation. Brazilian Journal of Medical and Biological Research, 45, 625-631.

Innis SM. 2006. Trans fatty intakes during pregnancy, infancy, and early childhood. Atherosclerosis Supplements, 7, 17-20.

Banerjee K. 2003. Prospective study of the association of changes in dietary intake, physical activity, alcohol consumption and smoking with nine-year gain in waist circumference among 16.587 US men. American Journal of Clinical Nutrition, 78, 719-727.

Mawi M. 2004. Indeks massa tubuh sebagai determinan penyakit jantung koroner pada orang dewasa berusia di atas 35 tahun. Jurnal Kedokter Trisakti, 23(3), 87-92.

Mozaffarian et al. 2006. Trans fatty acids and cardiovascular disease. New England Journal of Medicine, 354, 1601-13.

Muchtadi D. 2001. Sayuran sebagai sumber serat pangan untuk mencegah timbulnya penyakit 
Zaenudin dkk.

degeneratif. Jurnal Teknologi dan Industri Pangan, 12(1), 6-71.

Paeratakul et al. 2003. Fast-food consumption among US adults and children: dietary and nutrient intake profile. Journal of the American Dietetic Association, 103(10), 1332-1338.

Satchithanandam et al. 2004. Trans, saturated, and unsaturated fat in foods in the united states prior to mandatory trans-fat labeling. Lipids, 39, 11-18.

Silalahi J \& Tampubolon SDR. 2002. Asam lemak trans dalam makanan dan pengaruhnya terhadap kesehatan. Jurnal Teknologi dan Industri Pangan, Vol 13(2), 184-188.
[USDA] U.S. Department of Agriculture. 2011. Composition of Foods Raw, Processed, Prepared USDA National Nutrient Database for Standard Reference, Release 24. USDA Nutrient Data Laboratory, USA.

[WNPG] Widyakarya Nasional Pangan dan Gizi. 2004. Ketahanan Pangan dan Gizi di Era Otonomi Daerah dan Globalisasi. LIPI: Jakarta.

[WHO] World Health Organization. 2004. Mean Body Mass Index (BMI). http: / /www. who.int. 2008. Interim Summary of Conclusions and Dietary Recommendations on Total Fat \& Fatty Acids. Geneva: FAO/WHO Expert Consultation on Fats and Fatty Acids in Human Nutrition. 